\title{
Resilience in Discourses of the European Union and International Organizations ${ }^{1}$
}

\author{
E. Treshchenkov
}

Evgeny Treshchenkov - PhD, Associate Professor, St. Petersburg State University; Entrance VIII, 1/3 Smolnogo Str., St Petersburg, 191060, Russian Federation; E-mail: e.treschenkov@spbu.ru

\begin{abstract}
Lately, the European Union (EU) has faced multiple internal and external challenges. The conceptual response of EU institutions was "A Global Strategy for the European Union's Foreign and Security Policy" (June 2016). At the core of the understanding of what was happening, as well as of the prospects of overcoming those crises, sat the concept of "resilience." It has been some time since this concept appeared in the discourses of international organizations and its meaning remains volatile, situational and dependent on the scope of application, the relevant context and the authorship.

The purpose of this study is to examine the specificity of use of the concept of resilience in the discourses of the EU and various international organizations, as well as the interrelation between those uses. The sample encompasses organizations of particular importance to the European integration project and to global and regional governance, including the Council of Europe, the North Atlantic Treaty Organization (NATO), the Organization for Security and Co-operation in Europe (OSCE), the Organisation for Economic Co-operation and Development (OECD) and those which comprise the United Nations system (the International Monetary Fund (IMF), the World Bank, etc.). Since the empirical material consists mostly of official texts produced by international organizations, the preferred method of study is discourse analysis.

The analysis examines the Brussels-advanced notion of resilience from a more distant perspective, namely, within the coordinate system of global and regional governance represented by Western-dominated multilateral institutions. The study identifies channels and agents responsible for the concept's penetration into the discourses of the EU and other international organizations. Conclusions are drawn regarding similarities and divergences in the articulations of resilience. Particular focus is put on the interrelation between the concept and the neo-liberal approach to risk management and security.
\end{abstract}

Key words: European Union; United Nations; resilience; neo-liberalism; security; governance; experts

For citation: Treshchenkov E. (2019) Resilience in Discourses of the European Union and International Organizations. International Organisations Research Journal, vol. 14, no 1, pp. 55-75 (in English). DOI: 10.17323/1996-7845-2019-01-04

${ }^{1}$ The editorial board received the article in January 2017.

The study was made possible by a grant from the Russian Science Foundation (project No. 17-18-01110). 
While our feet are still wet from the wave of sustainability, a new wave has come our way bearing the name of resilience

During the past decade, the European Union (EU) encountered multiple internal and external challenges. Conceptually, it responded in part with "A Global Strategy for the European Union's Foreign and Security Policy” (June 2016) [EU, 2016], which replaced a document of a similar nature, namely, the European Security Strategy (2003). "Resilience" became the cornerstone for a renewed approach to the security problems of the EU. The concept of resilience has been around for some years, particularly in discussions on global governance. Moreover, the intensity of conceptualization applied to the relevant problematizing of the concept within the framework of the United Nations (UN) and other organizations has been steadily rising. Global governance itself, it seems, has been the subject of an active interest on the part of the EU [EU, 2012]. The very essence of the EU, as a community that came into being by way of multilateral cooperation, gives rise to stimuli for its own active backing of certain ways of dealing with international problems. The Europeans are among the most active members in organizations comprising the UN system. At the regional level the fora of European integration have traditionally included organizations intimately affiliated with the EU, including the Council of Europe, the North Atlantic Treaty Organization (NATO) and the Organisation for Economic Co-operation and Development (OECD).

The objective of this study is to illuminate the specificity of the use of resilience as a concept, as well as the interplay between its various interpretations and meanings within the discourses of the EU and international organizations relevant to the European project. Articulations of the notion of resilience within the discourses of organizations that approach problems of global governance and development in similar and often complementary ways are of interest as cases that may help not only to grasp the European discourse on the subject but also to shed light on some larger trends, e.g. the increasing role of resilience in governance and security discourses of western nations.

The article is structured as follows: first, the existent academic approaches to defining resilience and the latter's associations with the notions of security and risk management are discussed. A critical synthesis of the existing theoretical knowledge establishes an applicable framework for the selection and empirical analysis of relevant data. This discussion focuses particularly on the available reasoning that the notion belongs to neo-liberal discourse [Pavlova, Gudalov, Kotsur, 2017]. This is followed by an exploration of the meanings and context of the emergent concept of resilience within the discourses of EU institutions. The specifics of the treatment of resilience in the discourses of international organizations including the Council of Europe, NATO, the OECD, the Organization for Security and Co-operation in Europe (OSCE) and the UN system are examined, including the interrelation between the various interpretations of the notion and the approach taken by the EU. The intersections of those discourses with that of the EU are taken as a separate contextual factor of analysis.

This analysis draws mainly on the official papers of the EU, documents and materials from the official websites of the Council of Europe, the OSCE, NATO, the OECD 
and the UN system. Conceptually significant texts, e.g. Council of Europe conventions, were included in the sample regardless of whether there was any mention of resilience. For other texts, if there was such a mention, they were included in the sample (amounting to approximately 200 texts).

\section{The Concept of Resilience and the Framework for Analysis}

The concept of resilience came into the social sciences from the field of ecology. Initially, it was conceived as the ability of systems to absorb changes of variables and parameters. If the system is sufficiently resilient, the result will be its preservation, otherwise - disappearance. There is a fundamental distinction between resilience and stability, which is identified as the ability of a system to return to an equilibrium following a temporary shock. As the author of the concept Crawford Holling [1973, p. 17] noted, a system can be highly resilient but possess low stability, which is particularly characteristic of complex systems. It is highly likely that the EU is an instance of that class.

This potential to bring together the internal conditions of a system and the ambient shocks under a single category facilitated the onward use of the concept in psychology, economics and social sciences. A number of epistemic communities (e.g. the Resilience Alliance [Resilience Alliance, n.d.]) formed around the problem of resilience. As time went by, from being strictly an academic term resilience turned into a concept that inhabited the area of public policy. The end of the Cold War did not make the world any more predictable. On the contrary, the disappearance of the deterrent maintained by the bipolar confrontation, additionally complicated by a growing interdependence, gave rise to new crises and conflicts. Within the discourse of global governance, the category of resilience was enriching the lexicon of sustainable development. At various UN fora the need to strengthen the resilience of developing countries in the face of crises so as not to jeopardize the achievements that had been made through progress and international assistance was articulated.

New uses of the term were emerging under the bearing impact of some major international crises. The global economic crisis generated debate on economic resilience (within World Bank, OECD and IMF). The surge of international terrorism helped to propel the use of the concept in the context of ideological affinity and value-based cohesion of liberal democracies in the face of the terrorist threat (within NATO). All those dimensions were also, to a degree, mirrored in the official discourse of the EU. The active interest of managing officials in resilience gave further impetus to discussions within the academic community about the term's substance. Following those discussions, it is possible to identify several circumstances that offer potential interest for a comparative analysis of the discourses of international organizations.

One of those circumstances has to do with the multifaceted nature of meanings and articulations of resilience. Depending on contexts and situations, it shows varying facets as a term, as a conception and as an ideology [Anderson, 2015]. Drawing upon their analysis of dozens of scholarly publications, F. Brand and K. Jacks identified at least 10 different approaches to resilience. They argue that, originally articulated in the field of ecology, its meaning became blurred because of the interest from other academic disciplines. From a holistic and descriptive concept, resilience turned into a "boundary object." On the one 
hand, this facilitates communication across disciplines, enabling an even greater penetration of the term into political praxis. Yet, on the other hand, it does not help with the formation of a common approach to resilience. A veneer of consensus is being lacquered, whereas in fact the concept can acquire any meaning that one may wish. This also affects the prospects of for scholarly development and applicability of the concept. In this regard, resilience follows in the footsteps of "sustainable development" [Brand, Jax, 2007].

Another circumstance has to do with an obvious connection between resilience and security discourses. Frequently, resilience is contextualized as an element of the search for an adequate response to interconnected but hard-to-predict challenges, ranging from cyberattacks to flooding. And at the same time, in keeping with U. Beck's conception of risk society, it is not as much about trying to "overcome predictable or known threats" but rather about trying to "prepare for, adapt to and live with a spectrum of possible, perhaps unknowable risks" [Brasset, Croft, Vaughan-Williams, 2013, pp. 222-3]. According to this logic, risk is no longer an emergency but now is part of everyday life.

Some scholars associate the transition from traditional security policy to new methods of managing risks as a new governmentality. According to M. Foucault, its essence originates in the change that occurred in Western thinking about governance through rationalizing their (those who govern) own perception of the essences of governing and their view of the governed. In the same vein, resilience is visualized as a neo-liberal form of that very new governmentality. Moreover, liberalism should not be construed as some specific political ideology or economic theory, but exactly as "a principle and method of the rationalization of the exercise of government, a rationalization which obeys...the internal rule-of-maximum economy" [Foucault, 2008, p. 318]. The traditional approach supposed that the state takes care of known threats and enemies by way of their elimination. The new approach stresses the need to develop the inner qualities of social systems in order to face inevitable and unpredictable challenges, thereby utilizing the available resources in a more rational way. The state engages in "the entrepreneurial move to enjoin businesses, communities and individuals to manage their own risks." The goal is to create so-called "resilient subjects" [Brasset, Croft, Vaughan-Williams, 2013, p. 223-4].

Still, some in the academic community voice reasonable doubt about the novelty of the resilience concept. Thus, for example, neo-liberal discourse and the corresponding policy have long been in existence, yet, there is nothing of what is associated with resilience that would not be directly related to the former [Anderson, 2015, p. 63].

Having juxtaposed the research objectives and the current academic debate on the concept of resilience, the textual analysis developed in this article emphasizes the following six parameters. The first is authorship, which helps to deduce, for example, who within an organization (political leadership, bureaucracy or external experts) acts as a key agent of channeling resilience into discourse. Second is the context and field of application of resilience (economy, ecology, security, etc.). The third parameter is defined by concepts articulated in tandem with resilience (security, sustainable development, economic growth, risk management and the like). Among other things, this parameter allows determination of the correlation between resilience and the already existent terminology - whether used as a synonym, a qualification or a substitution for an "obsolete" notion. Definitions or attempts at defining the substance of resilience are the fourth parameter. In a narrow sense, 
it is suggestive either of using the concept as a "boundary" or in a holistic and unequivocal way. The fifth is defined by references to other international organizations regarding resilience, which allow identification of which organization poses as a donor of expertise on resilience and which acts as recipient. The final parameter is the interconnection between interpretations of resilience and neo-liberal practices. Indicative of such interconnections are, for example, uses of resilience in such contexts as decentralization and rationalization of governance. Whether a neo-liberal approach is taken or not can be evidenced through the prescriptions for attaining resilience as formulated by the authors of any particular text.

\section{Resilience in the European Union's Discourse}

Some researchers point to the fact that EU institutions have been using the term resilience in such areas as environmental policy and economy since the 1980s. The interest on the part of the European Environment Agency regarding the concept is understandable. In the last decade, the main domain of the term's circulation was the assistance to developing countries to prepare for natural disasters and emergency situations, which was made possible by joining the efforts of the EU, individual donor countries and organizations under the aegis of the UN. In that context, resilience was mentioned only sporadically, while its substance was never explicated [Romanova, 2017].

A more active penetration of the resilience concept into the discourse and political praxis of the EU began in 2011. That year, the European Commission (EC), following the UN, stated the need to tie humanitarian assistance to development policy with a focus on developing countries building their own resilience in the face of various kinds of disasters. Among the applications of the new approach was to the programme adopted in November 2011 to support the countries of the Horn of Africa affected by drought [EC, 2012a].

Both the EC's communication of 2012 [2012b] and the conclusions by the Council of the EU in 2013 formulated an approach to resilience that generally did not step out of the frame of UN discourse. Resilience, it was suggested, should be understood as "the ability of an individual, a household, a community, a country or a region to prepare for, to withstand, to adapt, and to quickly recover from stresses and shocks without compromising long-term development prospects" [Council of the EU, 2013]. It was noted that the EU had an understanding that it was necessary to eliminate the very causes behind crises, making the actions at the international and regional levels contingent on local and national praxis. In April 2014, the Directorate-General for International Cooperation and Development of the European Commission with support from the World Bank and the United Nations Development Programme (UNDP) prepared guidelines on resilience in the area of development policy. The guidelines summarized various EU programmes and projects that, according to the authors, exemplified good practices for forming resilience [EC, 2014]. It is noteworthy that similar guidelines on various aspects of resilience were released earlier by the OECD and the World Bank.

Yet, before the adoption of the Global Strategy for the European Union's Foreign and Security Policy (hereafter, Strategy 2016), the use of the term "resilience" had been limited to a few specific areas. Strategy 2016 brought resilience to the level of a key concept that, on the one hand, mirrored the sentiment of the proponents of the European project about the exis- 
tential nature of the challenges facing the united Europe, while on the other, the availability of recipes at the disposal of Brussels to overcome those challenges. As High Representative F. Mogherini insightfully noted in the preface to Strategy 2016, "the purpose, even existence of our Union is being questioned" [EU, 2016]. In that regard, Strategy 2016 is primarily about the resilience of the European integration project per se. This makes the EU significantly different from other international organizations. Unlike the UN, the EU is legitimately considered by many in Europe and beyond as a community based on common values and practices. This is the only ground to treat resilience from an existential perspective, rather than as an abstract category generated by the former metropoles' interest in their former colonies.

So far, however, the other components of the EU discussions on resilience have shown no evidence of major changes happening to the perception of threats or to the methods of their removal. Strengthening the resilience of the EU is viewed by the authors of Strategy 2016 with a focus on repairing the imbalances of governance in the EU in order to move forward to a greater value-based normative unity, using the ability of the EU to act independently in the international arena, advocating its core principles and values, as well as through efforts to facilitate the formation of resilient communities, states and economies bordering the EU. The methods of strengthening resilience of third countries remained unchanged. Having conceded the need to take into consideration the diverging national ways of attaining resilience, the authors of Strategy 2016 nonetheless remained insistent on proliferating the European model as universal [EU, 2016]. In this regard, resilience continues to be part of the old Eurocentric discourse that provoked the crises that are currently facing the EU.

As to the question of whether there is an interrelation between the neo-liberal approach and resilience in the discourse of the EU, the answer is yes. In most texts under review, strengthening resilience is associated with the call to be self-reliant with respect to system resources and to robustly engage actors of all types and levels in planning and preparation endeavours. By way of example, consider that the authors of the EU's cybersecurity strategy expect that the private sector will be able to act independently to provide resilience of the critical infrastructure, as well as to communicate to and coordinate with the public [EC, 2013].

There is a relative integrity of the EU's supranational discourse on resilience. EU institutions react in a timely way to the voiced positions, morphing them as much as possible into a single approach [European Parliament, 2017; Council of the EU, 2017]. Yet, some nuances remain. The EC, based on analysis of its documents, is to a significant degree affected by the discourses on resilience produced by World Bank and UN programmes. The European Parliamentary Research Service tends to concentrate on the OECD's methods when drawing policy briefs. It is not fortuitous that the relevant EU Parliament resolution recommends that the Commission and the Council take note of the OECD's methods as effective and practice-oriented [European Parliament, 2017]. On top of that, some Research Service papers which offer detailed analyses of the connections between various aspects of resilience and foreign policy had been released prior to the 2016 strategy that turned it into a key category [Pawlak, 2015]. It is quite obvious that the indicated organizations (OECD, World Bank) and the experts associated with them wield enormous influence in shaping the EU's approaches to global governance and to resilience as an element of the latter. 


\section{EU's Engagement with International Organizations}

Given the history of origins of the European Communities and the very essence of the association, multilateral diplomacy has been a fundamental principle of the EU's action in the international arena. The Treaty on the EU clearly states the idea of an active participation in global and regional governance with an emphasis on promoting the European model around the world [EU, 2012]. Among all types of international organization, it prioritizes those of the UN system, including the International Monetary Fund, the World Trade Organization (WTO) and the World Bank Group. Other international organizations with which the EU should have structured in-depth cooperation include the Council of Europe, the OSCE, the OECD and NATO.

The Council of Europe and NATO have traditionally formed the basis of European integration. The former serves as a large cultural and legal forum for European integration. The intersection between political discourses of the Council of Europe and those of the EU is facilitated by incorporating European conventions and European Court of Human Rights decisions into the EU's legal order. The EU institutions are guided by standards of the Council of Europe and its various units (e.g. the European Commission for Democracy through Law) in their relations with third countries, referring to them in official papers. NATO has been providing the security umbrella under which the West European model of economic integration could form. Despite having had its own Common Security and Defense Policy since the mid-1990s, members and institutions of the EU regularly avow that the North Atlantic Alliance is key to European security. The discourses of the two organizations on matters of military security in Europe are intertwined. This was possible in part through experts and officers crossing over between the bureaucracies. Further, there seems to exist a certain axiological unity of western nations.

The OECD, known from 1948-1961 as the Organization for European Economic Cooperation, was initially tasked with implementing the Marshall Plan. The OECD contributed to building the economic foundation of European integration and to developing certain practices of economic management and reform. Today, the organization serves as a forum for sharing experience in implementing economic reforms and managing socioeconomic developments. The EU's institutions turn to OECD experts, while their programmes often demonstrate moral unity and similarity of the approaches taken.

The OSCE was intended to serve as a forum for interaction between the western and eastern parts of the European continent. The principles of international cooperation, as set forth in the final act of the Commission on Security and Cooperation in Europe, are an integral part of international law. With the end of the Cold War, there were high hopes regarding the OSCE; however, it failed to establish the basis for a full-fledged system of European security. The current discourse of the organization, much like its policy, is heavily influenced by Western approaches, of which the OSCE is frequently accused by Russia and a few other countries. Judging by its share within the OSCE's bureaucracy, as well as by its participation in discussions and expertise of the organization, Russia is significantly behind the EU countries. At the same time, it is exactly the mechanisms of the OSCE that the conflicting parties of Russia and the West turned to when the Ukrainian crisis erupted. 
The organization remains the very institution whose representatives enjoy a significantly higher degree of trust from Russia than do those of NATO. The official documents drawn up by both Russia and the EU and its members on a range of aspects of security and cooperation in Europe retain references to the OSCE and its practices.

It is crucial to understand that the comfort of interaction between the EU and the aforementioned international institutions is determined in part by the fact that the current structure of global governance is dominated by Western institutions. The discourses of the World Bank, the IMF, UN programmes, the Council of Europe, the OSCE and the OECD were formed with an active input from the U.S. and West European states. As European integration grew more profound, some supranational institutions (mostly the European Commission) began to take part in those discourses. The rate of interaction between the EU and those international organizations depends on the relative membership share of the EU countries in them (with an overlap starting from one-half of their number to a virtually complete coincidence). One could therefore expect that the chances for the Anglo-Saxon concept of resilience to penetrate organizations and structures with a significant presence of non-Western states (Russia, China, etc.) will be limited.

\section{Resilience in the Discourses of International Organizations}

The notion of resilience emerged in the discourses of international organizations primarily as a result of their officials interacting with expert communities in such fields as ecology and economy. Evidently this was the pattern that the OECD and the UN organizations followed, including the IMF and the World Bank. The presence of resilience in their discourses is quite discernible, which is further evidenced by numerous references made to them in the relevant EU papers. It is a rare EU document that, while mentioning resilience in the context of global governance or development policy, would not also invoke the relevant UN initiatives such as the Sustainable Development Goals and the Sendai Framework for Disaster Risk Reduction.

As noted, the UN system uses the concept of resilience in a variety of ways, from resilience to natural disasters to economic resilience. As expected, it is used most seldom in the discourses of such structures as the General Assembly and the Security Council. Thus, out of all Security Council resolutions for 2013-2017, only two contained a reference to resilience and no definition or disclosure of its substance was given. In 2014, it was about local community resilience [UN Security Council, 2014], whereas in 2017, the context was that of countering international terrorism [UN Security Council, 2017]. Significantly more frequently, even in the context of security, the traditional category of sustainability was used.

Political discourses of many UN members, particularly those who are not directly targeted by programmes that have to do with resilience, seem to contain no such category. So, the Russian language version of the General Assembly resolution on global development goals handles resilience by three different interpretations within a single document - once as "viability" (cities, the indigent), another time as "durability" (infrastructure) and finally as "stability" (agrarian systems) [UN General Assembly, 2015].

It comes as no surprise that those UN organizations and programmes that heavily relied on Anglophone expertise in highly specialized areas were among the most receptive 
to the concept. Intensive project communication and revolving doors between the international bureaucracy personnel and the expert communities facilitated the penetration by academic resilience studies into the practical agenda of the UN. This is the case, first and foremost, of the UN International Strategy for Reduction (UNISDR), the UNDP, the World Bank Group and the IMF.

A testimony to the conceptual nature of resilience in UN discourse is one of its key initiatives, namely the Sustainable Development Goals. The relevant General Assembly resolution mentions resilience about two dozen times in reference to infrastructure, urbanism, refugees and natural disasters [UN General Assembly, 2015]. Yet, its set of problems and approaches to tackle them could hardly be described as a fundamentally new conceptualization of the development policy problematics. Resilience does not replace the concept of sustainable development but rather complements it by shifting the emphasis of the UN organizations' work toward local resources and capabilities of objects to global governance. As the UN secretary-general noted, together the three interdependent UN pillars (peace, sustainable development and human rights) "form the basis of resilient and cohesive societies" [United Nations Secretary-General, 2016b].

The other important participants of UN discourse are the World Bank Group and the IMF. This is due mainly to the fact that these organizations attempt to develop a toolbox for gauging resilience and also because they are perceived around the world as agents of the overarching neo-liberal approach to solving global and regional problems. With respect to applying the neo-liberal approach to governance as a rationalization practice, it is obviously a characteristic of both the IMF and the World Bank, as well as of the majority of UN programmes. It is universally assumed within their discourses that individuals, social groups and local communities possess intrinsic resilience potential to withstand crises and other challenges. In this vein, the UN secretary-general, in an act of admiration for the resilience of refugees, cited the example of a Syrian refugee camp whose residents had created from scratch an entire infrastructure that they had been accustomed to, spanning restaurants, shopping markets, art galleries and sports gyms [United Nations Secretary-General, 2016a].

The World Bank's president named strengthening resilience to counter global shocks and threats among the three foci of the Group. The other two are boosting sustainable economic growth and investment in human capital [World Bank, 2016a]. Investments in human capital are aimed in part at developing the intrinsic potential and capabilities of individuals, who are the first to suffer the consequences of natural disasters and emergencies. World Bank experts focus their studies on the definition of the concept of resilience, as well as on the methods of gauging it. They draw particular attention to developing the category of socio-economic resilience. Their relevant reports provide a detailed methodology and a system of indicators for gauging it [World Bank, 2016b, p. 3]. Resilience is defined as the ability of communities or societies to adapt to a negative impact. This ability is attained through resilience or by changing the system so as to maintain an acceptable level of functioning and integrity of structure. Such aspects of resilience as the system's ability to self-organize, learn and adapt are particularly emphasized [Prasad et al., 2009, p. 33]. Following C. Holling, World Bank experts believe that complex and diverse systems possess more resilience. After all, when resources or capacities are in the hands of various interest groups (the state, business and local communities) there exist more options for testing different approaches and solutions [Ibid., p. 34]. 
The discourse of the IMF has used the concept of resilience since the 1990s. It is noteworthy that the context of the term's use has not changed - it is still about the resilience of economies and financial systems in the face of crises. IMF experts admit that there is no single template to build resilience [IMF, 2015]. Still, when used, the concept is situated within the contexts of traditional categories of IMF discourse and political praxis (structural reforms, macroeconomic stabilization), indicating that the same "universal" recipes and models are being promoted. Also questionable is the presumed neo-liberal nature of resilience. Analysis of the causes of financial crises and currency imbalances have prompted the IMF to conclude that these are due to the "irresponsibility of market participants" and that there is a need to strengthen the supervisory role of national regulators and those of international financial institutions [IMF, 2005]. Concurring with the IMF conclusions are members of academic community who contend that such neo-liberal practices such as privatization of critical infrastructure may carry security risks [Walker, Cooper, 2011, p. 153].

Despite the OECD's relatively late engagement with resilience, the approach it has taken is one the most systemic and profound. The organization releases voluminous guides designed to help experts and practitioners in the field to develop the instruments for gauging and embedding resilience into their humanitarian programmes [OECD, 2014a]. Naturally, OECD methods gained the immediate attention of the European Parliamentary Research Service, while the recommendations for their use became part of European Parliament's resolutions. A major event that contributed to further interest for the organization and the concept of resilience was the global financial and economic crisis of 2008 and its consequences. In this respect, the OECD's experience is similar to that of the IMF. When defining the notion of resilience, OECD experts particularly emphasize the ability not only to withstand an unfavourable impact and to recover, but also, having learned from the experience, to become stronger. To them, to be resilient means to be able to recognize the sources of risks and opportunities, and to learn to live with uncertainty [OECD, 2014b].

Also, according to OECD discourse, resilience is a multilayered phenomenon. Different layers (individual, local communities, public institutions, the international arena) tend to have different sets of risks and ways of managing them [OECD, 2013]. They propose to gauge resilience along four interdependent dimensions - economic, social, institutional and environmental [OECD, 2014b].

The attention of the OECD experts is mostly focused on the resilience of developing countries. They view it as a guarantee that invested international assistance will not be lost due to the collapse of the economy or the state. The opposite of resilience is the proposed concept of state fragility. In the event of the latter, the prime task of the international community is to assist in the restoration of statehood by reaching an effective social compact between the state and society [OECD, 2008].

The OECD experts also tried to answer the question of the practicality of resilience as a concept for managing risks. In their view, an analysis of the system's resilience cannot replace traditional approaches to risk management but, it does draw on and complement the latter. In particular, such analysis does not focus on the risk per se, but on the system and the record of its past performance, as well as on the analysis of trends, taking into account uncertainty and constant risk fluctuations [OECD, 2014a]. Their call to pay special 


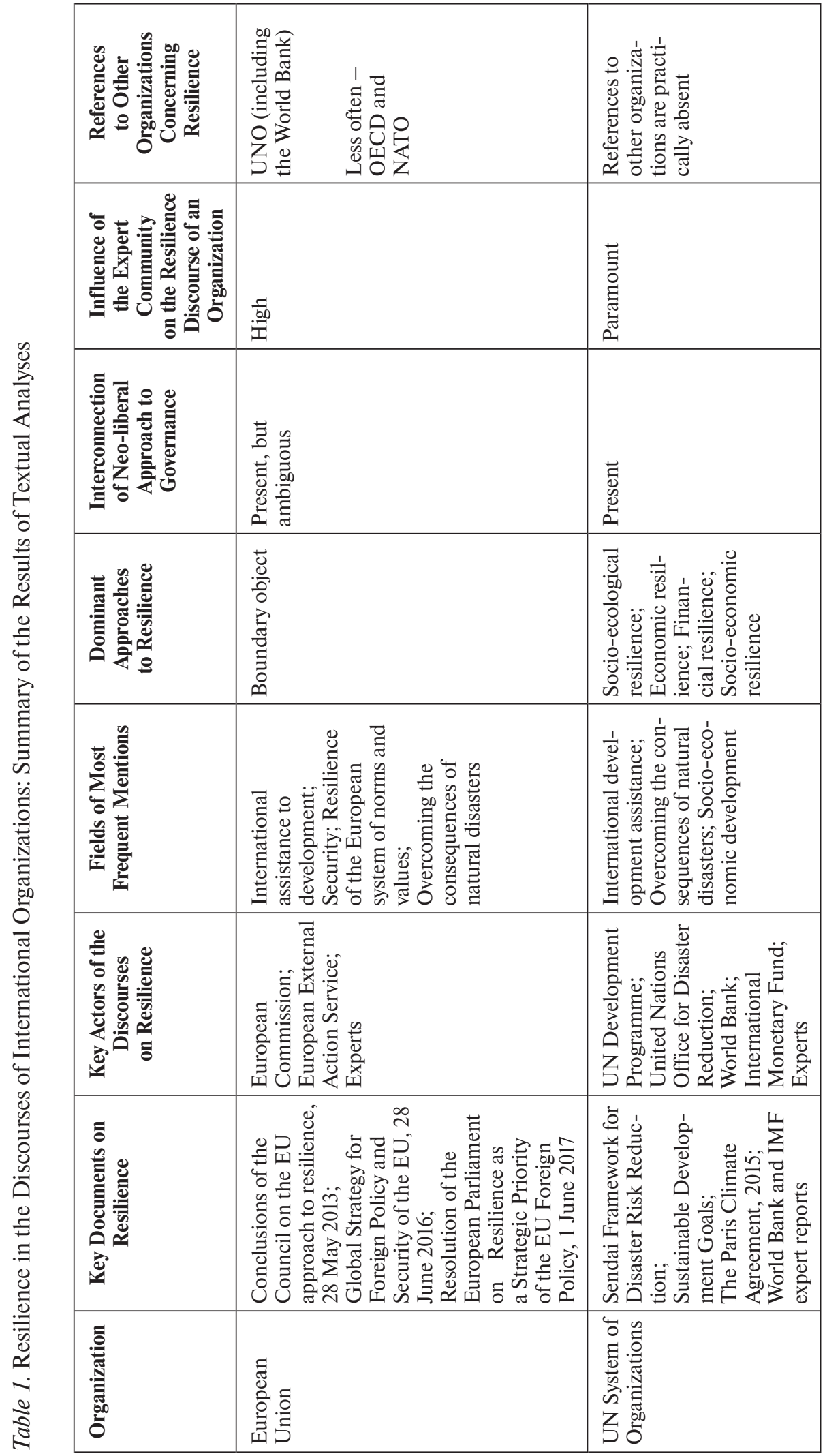




\begin{tabular}{|c|c|c|c|c|}
\hline 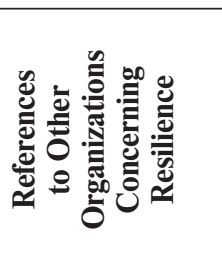 & $\stackrel{\circ}{Z}$ & 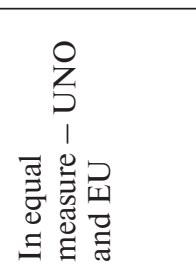 & 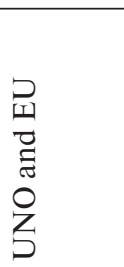 & 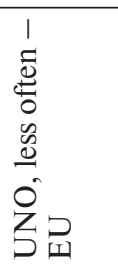 \\
\hline 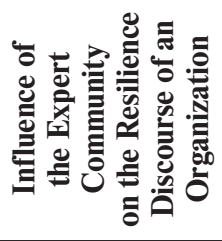 & 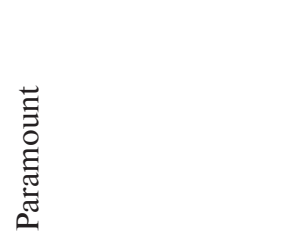 & 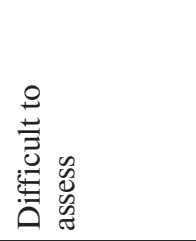 & 1 & 1 \\
\hline 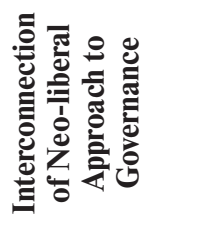 & 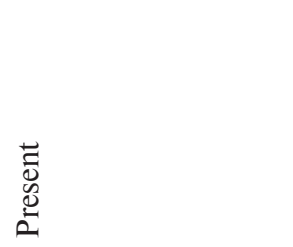 & 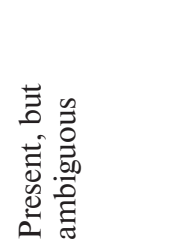 & 1 & I \\
\hline 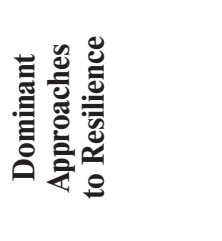 & 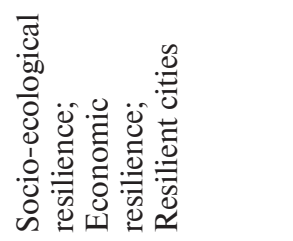 & 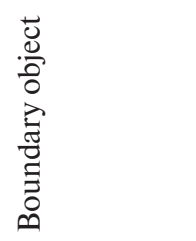 & 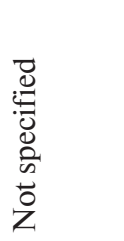 & 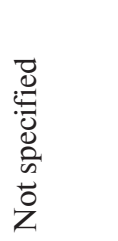 \\
\hline 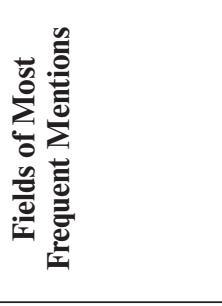 & 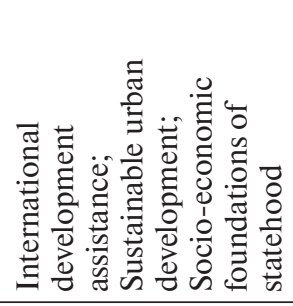 & 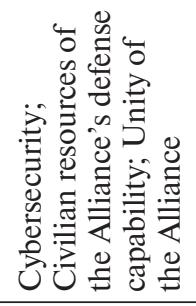 & 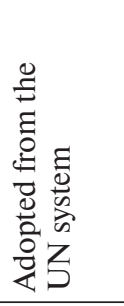 & 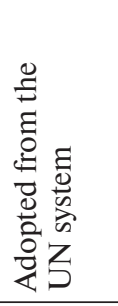 \\
\hline 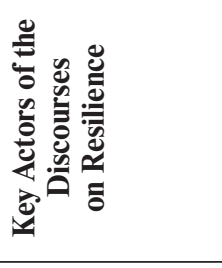 & 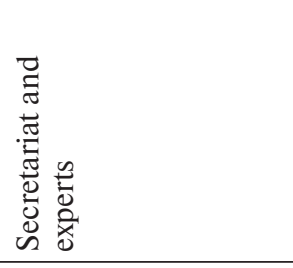 & 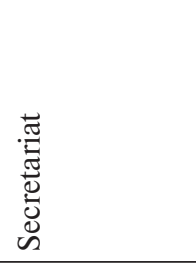 & 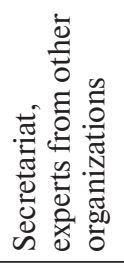 & 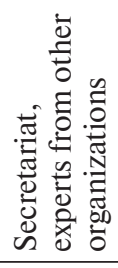 \\
\hline 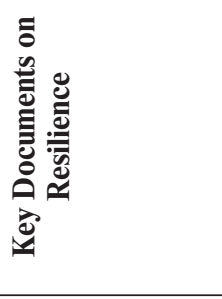 & 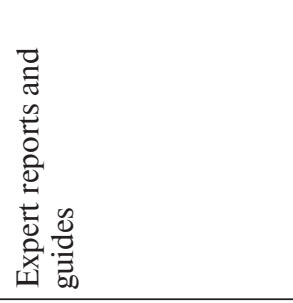 & 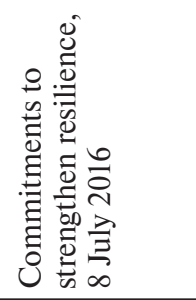 & 1 & | \\
\hline & 己ે & 은 & 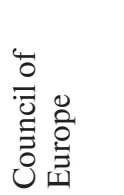 & 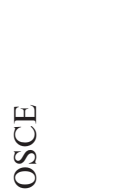 \\
\hline
\end{tabular}


attention to data collection, development of methods of analysis and identification and forecasting of possible risks based on such analysis places the OECD in close quarters with the World Bank and the IMF, and then with the European Union. Of late, the concept of "big data" has increasingly been mentioned in this context [World Bank, 2015].

Resilience is not a key concept in the discourses of the Council of Europe or the OSCE and is in use only when the programmes or interests of these organizations become congruent with the initiatives of the UN system. The channels through which resilience is transmitted from the discourses of the UN into the agendas of the OSCE and the Council of Europe are the various joint conferences and events at which the actors are vested experts (e.g. of the Swiss Agency for Development and Cooperation, autonomous part of the MFA). Currently, the Council of Europe and the OSCE have no expert knowledge on resilience to offer the EU, for they are among the recipients of it themselves (See Table 1).

Localization of the resilience concept at the ground level by Anglophone experts who shift through and between the multilateral institutions can be largely explained by the absence of this category in the discourses of a significant number of the members of the Council of Europe and the OSCE. A good example of this is the report by an international collective of authors (including from Russia) prepared under the auspices of the OSCE in 2015, containing proposals to end the crisis in relations between Russia and the West. The text of the report uses the term "sustainable," while the preview of the report, which was prepared by the OSCE secretariat, talks about the "resilience" of European security [OSCE, 2015].

The relative recency and ambiguity of interpretation of the concept does not allow it to be used in the Council of Europe conventions, even when the subject would imply such use (e.g. preserving city landscapes). Neither the conventions, nor the protocols to them, including those adopted over the past decade, mention the concept of resilience. ${ }^{2}$ A contributing factor to the inability of ambiguous notions to take hold in the discourses of these organizations is the existence of contradictions between members. As is well known, besides member countries of the EU, Russia and a few post-Soviet states also hold membership with both organizations.

Standing apart is NATO. The notion of resilience has been part of NATO's discourse since the 1990s; however, the use of the term was irregular and devoid of any serious conceptual bearing. It was mostly referred to by the Alliance's political leadership (SecretariesGeneral G. Robertson and H. Solana) when characterizing NATO's overall ability to adapt to changed conditions and new security challenges [Solana, 1997]. The Alliance's treatment of resilience as an internal criterion has remained unchanged. With the rise of international terrorism, resilience was repeatedly invoked within the context of the unity of the transatlantic community of values in the face of this threat. This strictly endogenous reading of resilience would be later encountered in Strategy 2016, as well as within the context of the Alliance's own perception of Russia's policy in the region as a threat [NATO, 2014].

The transformation of resilience within NATO discourse from a situational concept into a more or less holistic one had occurred by 2016. From 2016-2017, resilience was mentioned in the official texts of the Alliance more often than it had been over the entire period

\footnotetext{
${ }^{2}$ For more, visit http://www.coe.int/en/web/conventions/full-list.
} 
since the 1990s, coinciding with the activation of the concept within the EU discourse. It became the main topic for the first time at the NATO Warsaw summit (July 2016) as is evidenced from the joint statement of the heads of states and governments released at the event's conclusion. Obviously, the activation of the concept within NATO had to do with its awareness of Europe's vulnerability to the so-called hybrid threats. The latter were defined as the use of asymmetric tactics intended to tap into and take advantage of the vulnerabilities of adversaries, using non-military means (political, informational, economic) and accompanied by a threat to use conventional weapons and weapons of mass destruction [NATO, 2015]. Undoubtedly, lately Russia has been referred to as a major source of such threats, placed immediately after international terrorism. This fact, obviously, is just another point of intersection in the discourses of NATO and the EU on resilience. A joint statement of the EU and the Alliance on 8 July 2018 asserted that the Euro-Atlantic community had encountered unprecedented challenges from the southern and eastern directions [EC, 2016]. A more explicit statement by the Alliance emphasized the need to take into account and address "potential vulnerabilities that can arise from Russia's involvement in business, financial, media or energy concerns" in Europe [Shea, 2016].

Meanwhile, this activation of the resilience concept in the discourse of the Alliance was not followed by any fundamental change in the perspective on the internal capabilities and the applied criteria of the organization. The personnel of the civil and military staffs made resilience part of the existing conceptual framework for strategic planning. It was particularly emphasized that the need to strengthen the resilience of the Alliance arose from the provisions of NATO (Articles 3 and 5). Resilience itself was defined as "the combination of civil preparedness and military capacity" [NATO, n.d.] of the Alliance, while the set of measures for strengthening it relied on the existing programmes and instruments.

\section{Conclusion}

Discussions concerning resilience in various international organizations and fora relate to the notion that the modern challenges to international development and security are not only complex and interdependent but also, to a large degree, unpredictable. As B. Anderson [2015, p. 63] notes, resilience can be viewed as a way to manage insecurity in today's world of disasters. The penetration of resilience into the discourses of international organizations bespeaks a general confusion before a series of hard-to-predict crises and appears to be an attempt to instill in both the governed and those who govern a sense of confidence as to the possibility of overcoming those crises successfully.

In the meantime, a feature of the international organizations' discourses is their disregard for the fact that modern risks do not simply emerge out of the blue but rather are produced within and by systems. Those crises are built-in components of rationalized decision-making, which sends us back to neo-liberal practices. As N. Luhmann [1994] remarked, "we can speak of risk only if we can identify a decision without which the loss could not have occurred." In a similar vein, the identification of risks to the stability of the European integration project must be an element of the analysis of decisions taken at all levels of European decision-making, i.e. an element of the very policy of the EU. Likewise, 
decisions taken by national governments following IMF recommendations, for example, are inevitably accompanied by corresponding risks to their socio-economic, financial, and political systems.

A commonality for all organizations examined in this study was the interdependency between their interpretations of resilience and the neo-liberal approach to governance (see Table 1). The rationalization of the view of the system's capabilities and resources is characteristic of both hard security and development policy. Some NATO documents explain in detail what is implied by civil capabilities of resilience of the Alliance, while the discourse of the World Bank refers to capabilities and criteria for socio-economic resilience of developing countries. Still, the degree of proposed autonomy for the supervised in an act of strengthening their resilience is strongly dependent on the assessment of their capabilities, as well as on their political culture and the focal area of the organization. The closer the latter is to so-called high politics, the less autonomy is offered to the private sector (a salient example is NATO). The same holds true for the capabilities of the supervised. When the focus is on the resilience of society of an EU Member State, a high level of autonomy is assumed. In cases with developing countries, the focus is on the guiding role of the donor's assistance in building resilience.

The degree of novelty of the resilience concept in most cases is not very high. With a varying success rate all organizations have integrated resilience into their existing discourses by complementing rather than replacing categories such as sustainable development, security and risk management (see Table 2). The most profound elaboration of resilience can be observed in those organizations whose scope of activity includes the development of expertise, methodologies and instruments for global and regional governance. Among such

Table 2. Notions That Are Most Frequently Used in Association with Resilience

\begin{tabular}{|c|c|c|c|c|c|c|c|c|}
\hline \multicolumn{9}{|c|}{ SECURITY } \\
\hline \multicolumn{2}{|c|}{ RISKS } & \multicolumn{2}{|c|}{ Terrorist attack } & \multicolumn{2}{|c|}{ Climate Change } & \multicolumn{2}{|c|}{ DISASTERS } & CRISES \\
\hline \multicolumn{3}{|c|}{ VULNERABILITY } & & & & & & Fragility \\
\hline \multicolumn{2}{|c|}{ RISK MANAGEMENT } & & ness & \multicolumn{3}{|c|}{ Preparedness } & Prevention & Defense \\
\hline System & \multicolumn{2}{|c|}{ Capabilities } & \multicolumn{2}{|c|}{ Capacity } & \multicolumn{2}{|c|}{ Infrastructure } & Institutions & Society \\
\hline \multicolumn{9}{|c|}{$\begin{array}{c}\text { Solidarity, Effectiveness, Coherence, Flexibility, Innovation, Connectivity, Cohesion, Complementarity, } \\
\text { Resourcefulness, Inclusiveness, Integration, Dynamism, Smart, Renewable }\end{array}$} \\
\hline SUSTAI & LITY & & $\begin{array}{l}\text { AINA } \\
\text { LOPM } \\
\text { LOPN }\end{array}$ & $\begin{array}{l}\text { LE } \\
\text { NT, } \\
\text { NT }\end{array}$ & Adap & tion & $\begin{array}{r}\text { Econo } \\
\text { grow }\end{array}$ & Stability \\
\hline
\end{tabular}

The data have been compiled for all organizations. Key concepts are in capital letters. 
organizations are the World Bank and the OECD. Their experts are clearly trying to move away from ambiguity in understandings of resilience. In the meantime, from the viewpoint of the EU, it is still treated as a general approach and a "boundary object" that enables communication between different areas of EU policy. Such an approach is fraught with vulnerabilities. An illusion of consensus disguises substantial differences in articulations.

As far as one can see, the inclusion of resilience within the discourses of the leading international organizations is happening without Russia's input. This has to do in part with the Anglo-Saxon origins of the notion. Another important reason is the existing normative and ideological contradiction between the West on one side and Russia and a few other countries on the other. They speak different languages, which affects the degree to which their discourses mutually intersect. As a consequence of their conflict, running along the fault line between Russia and the West, the talks on Russia's accession to the OECD, a key organization from the standpoint of elaborating the resilience concept, have been suspended. Moreover, the concept of resilience in EU and NATO discussions is directly linked to the discussion of Russia's policy as threatening European security. This circumstance and the fact that NATO and the EU treat resilience as an internal criterion of their unity sets the discourse of the so-called "Euro-Atlantic community" apart from those of the other organizations studied in this article.

\section{References}

Anderson B. (2015) What Kind of Resilience? Politics, vol. 35, no 1, pp. 60-66.

Brand F.S., Jax K. (2007) Focusing the Meaning(s) of Resilience: Resilience as a Descriptive Concept and a Boundary Object. Ecology and Society, vol. 12, no 1. Available at: http://www.ecologyandsociety. org/vol12/iss1/art23/ (accessed 25 October 2017).

Brassett J., Croft S., Vaughan-Williams N. (2013) Introduction: An Agenda for Resilience Research in Politics and International Relations. Politics, vol. 33, no 4, pp. 222-223.

Council of the European Union (EU) (2013) Council Conclusions on EU Approach to Resilience. Brussels, 28 May. Available at: http://www.consilium.europa.eu/uedocs/cms_data/docs/pressdata/EN/ foraff/137319.pdf (accessed 25 October 2017).

Council of the European Union (EU) (2017) EU Engagement with Civil Society in External Relations: Council Conclusions. Brussels, 19 June. Available at: https://www.consilium.europa.eu/media/24003/ st 10279en17-conclusions-eu-engagement-with-civil-society-in-external-relations.pdf (accessed 20 December 2018).

European Commission (EC) (2012a) SHARE: Supporting Horn of Africa Resilience. Commission Staff Working Document SWD (2012) 102 Final. Brussels, 4 November.

European Commission (EC) (2012b) The EU Approach to Resilience: Learning From Food Security Crises. Communication from the Commission to the European Parliament and the Council COM (2012) 586 Final. Brussels, 3 October.

European Commission (EC) (2013) Cybersecurity Strategy of the European Union: An Open, Safe and Secure Cyberspace. Joint Communication to the European Parliament, the Council, the European Economic and Social Committee and the Committee of the Regions. JOIN (2013) 1 Final. Brussels, 2 July.

European Commission (EC) (2014) EU Resilience Compendium: Saving Lives and Livelihoods. Available at: http://ec.europa.eu/echo/files/policies/resilience/eu_resilience_compendium_en.pdf (accessed 25 October 2017). 
European Commission (EC) (2016) Joint Declaration by the President of the European Council, the President of the European Commission and the Secretary General of the North Atlantic Treaty Organization. Brussels, 8 July. Available at: http://europa.eu/rapid/press-release_STATEMENT-16-2459_ en.htm (accessed 25 October 2017).

European Parliament (2017) Resilience as a Strategic Priority of the External Action of the EU. Resolution 2017/2594(RSP). Brussels, 1 June. Available at: http://www.europarl.europa.eu/sides/getDoc. do?pubRef=-//EP//TEXT+TA+P8-TA-2017-0242+0+DOC+XML+V0//EN (accessed 25 October 2017).

European Union (EU) (2012) Consolidated Version of the Treaty on European Union. Official Journal of the European Union. 26 October.

European Union (EU) (2016) Shared Vision, Common Action: A Stronger Europe. A Global Strategy for the European Union's Foreign and Security Policy. Available at: https://europa.eu/globalstrategy/en/ shared-vision-common-action-stronger-europe (accessed 25 October 2017).

Foucault M. (2008) The Birth of Biopolitics. New York: Palgrave Macmillan.

Holling C.S. (1973) Resilience and Stability of Ecological Systems. Annual Review of Ecology and Systematics, vol. 4, pp. 1-23.

International Monetary Fund (IMF) (2005) Remarks by Agustín Carstens, IMF Deputy Managing Director, at the VIII Annual Assembly of Supervisors of Banks of the Americas, 9 September. Available at: http://www.imf.org/en/news/articles/2015/09/28/04/53/sp090905 (accessed 25 October 2017).

International Monetary Fund (IMF) (2015) IMF Survey: Inclusion, Governance, Fiscal Space Can Help Overcome Fragility. Available at: http://www.imf.org/en/news/articles/2015/09/28/04/53/sopol070115a (accessed 25 October 2017).

Luhmann N. (1994) Ponjatie riska [The Notion of Risk]. Thesis, vol. 5, pp. 135-160. (In Russian)

North Atlantic Treaty Organization (NATO) (2014) Summit Declaration. Wales, 5 September. Available at: http://www.nato.int/cps/en/natohq/official_texts_112964.htm?selectedLocale $=$ en (accessed 25 October 2017).

North Atlantic Treaty Organization (NATO) (2015) Hybrid Warfare: NATO's New Strategic Challenge? Defence and Security Committee General Report DSC 2015, 10 October. Available at: https://www. nato-pa.int/sites/default/files/documents/2015\%20-\%20166\%20DSC\%2015\%20E\%20BIS\%20-\%20 HYBRID\%20WARFARE\%20-\%20CALHA\%20REPORT.docx (accessed 25 October 2017).

North Atlantic Treaty Organization (NATO) (c. a.) Civil Preparedness. Available at: http://www.nato. int/cps/en/natohq/topics_49158.htm?selectedLocale=en (accessed 25 October 2017).

Organisation for Economic Co-operation and Development (OECD) (2008) Concepts and Dilemmas of State Building in Fragile Situations: From Fragility to Resilience. OECD/DAC Discussion Paper. Available at: https://www.oecd.org/dac/conflict-fragility-resilience/docs/41100930.pdf (accessed 25 October 2017).

Organisation for Economic Co-operation and Development (OECD) (2013) What Does "Resilience" Mean for Donors? An OECD Factsheet. Available at: http://www.oecd.org/dac/May\%2010\%202013\%20 FINAL\%20resilience\%20PDF.pdf (accessed 25 October 2017).

Organisation for Economic Co-operation and Development (OECD) (2014a) Guidelines for Resilience Systems Analysis. Strasbourg: OECD Publishing.

Organisation for Economic Co-operation and Development (OECD) (2014b) Overview Paper on Resilient Economies and Societies. Meeting of the OECD Council at Ministerial Level. Paris, 6-7 May. Available at: https://www.oecd.org/mcm/C-MIN(2014)7-ENG.pdf (accessed 25 October 2017).

Organization for Security and Co-operation in Europe (OSCE) (2015) Back to Diplomacy: Final Report and Recommendations of the Panel of Eminent Persons on European Security as a Common Project. Available at: http://www.osce.org/networks/205846 (accessed 25 October 2017).

Pavlova E., Gudalov N., Kotsur G. (2017) "Stressoustojchivost' : novoe slovo v mezhdunarodnyh otnosheniyah ili variaciya na neoliberal'nuyu temu? ["Resilience:” A New Word in International Relations 
or a Variation on a Neoliberal Theme?]. The Moscow University Herald, Series 25. International Relations and Politics, no 2, pp. 170-182. (In Russian)

Pawlak P. (2015) Risk and Resilience in Foreign Policy. European Parliamentary Research Service Briefing PE 568.349. Available at: http://www.europarl.europa.eu/RegData/etudes/BRIE/2015/568349/ EPRS_BRI(2015)568349_EN.pdf(accessed 25 October 2017).

Prasad N., Ranghieri F., Shah F., Trohanis Z., Kessler E., Sinha R. (2009) Climate Resilient Cities: A Primer on Reducing Vulnerabilities to Disasters. Washington, DC: World Bank.

Romanova T. (2017) Kategorija "Stressoustojchivost" v Evropejskom Sojuze [The Concept of Resilience in the European Union]. Contemporary Europe, no 4, pp. 17-28. (In Russian).

United Nations (UN) Secretary-General (2016a) Secretary-General's Joint Press Encounter with the High Commissioner for Refugees, 30 March. Available at: https://www.un.org/sg/en/content/sg/pressencounter/2016-03-30/secretary-generals-joint-press-encounter-high-commissioner (accessed 25 October 2017).

United Nations (UN) Secretary-General (2016b) Secretary-General's Message on Human Rights Day, 10 December. Available at: https://www.un.org/sg/en/content/sg/statement/2016-12-10/secretary-generals-message-human-rights-day-scroll-down-french (accessed 25 October 2017).

Shea J. (2016) Resilience: A Core Element of Collective Defence. 2016 NATO Review. Available at: http://www.nato.int/docu/review/2016/Also-in-2016/nato-defence-cyber-resilience/EN/index.htm (accessed 25 October 2017).

Solana H. (1997) Security Through NATO in the 21st Century: Vision to Reality. Opening Remarks, 9 October. Available at: http://www.nato.int/cps/en/natohq/opinions_25565.htm?selectedLocale=en (accessed 25 October 2017).

Thomas J. (2016) Resilience: More Than a Quick Fix. Investing in Health: News and Views in Healthy Development World Bank Blog. Available at: http://blogs.worldbank.org/health/resilience-more-quickfix (accessed 25 October 2017).

United Nations (UN) General Assembly (2015) Transforming Our World: The 2030 Agenda for Sustainable Development. General Assembly Resolution A/RES/70/1. Available at: http://www.un.org/ga/ search/view_doc.asp?symbol=A/RES/70/1\&Lang=E (accessed 25 October 2017).

United Nations (UN) Security Council (2014) The Maintenance of International Peace and Security: Security Sector Reform: Challenges and Opportunities. Security Council Resolution S/RES/2151.

United Nations (UN) Security Council (2017) Threats to International Peace and Security Caused by Terrorist Acts. Security Council Resolution S/RES/2341.

Walker J., Cooper M. (2011) Genealogies of Resilience: From Systems Ecology to the Political Economy of Crisis Adaptation. Security Dialogue, vol. 4, no 2, pp. 143-160.

World Bank (2015) Big Data for a More Resilient Future. Available at: http://live.worldbank.org/bigdata-for-a-more-resilient-future (accessed 25 October 2017).

World Bank (2016a) Speech by World Bank President Jim Yong Kim: The World Bank Group's Mission: To End Extreme Poverty, 3 October. Available at: http://www.worldbank.org/en/news/speech/2016/10/03/ speech-by-world-bank-president-jim-yong-kim-the-world-bank-groups-mission-to-end-extreme-poverty (accessed 25 October 2017).

World Bank (2016b) Socioeconomic Resilience Multi-Hazard Estimates in 117 Countries. World Bank Policy Research Working Paper 7886. 


\title{
Стрессоустойчивость (resilience) в дискурсах Европейского союза и международных организаций ${ }^{1}$
}

\author{
Е.Ю. Трещенков
}

Трещенков Евгений Юрьевич - к.и.н., доцент кафедры международных отношений на постсоветском пространстве факультета международных отношений Санкт-Петербургского государственного университета; Российская Федерация, 191060, Санкт-Петербург, ул. Смольного, д. 1/3, подъезд 8; E-mail: e.treschenkov@ spbu.ru

В последние годы Европейский союз столкнулся с множественными внутренними и внешними вызовами. В концептуальном плане одним из ответов управленцев Евросоюза стала Глобальная стратегия внешней политики и безопасности (июнь 2016 г.). Ядром видения происходящего, а также перспектив выхода из кризиса стала концепция стрессоустойчивости (resilience). Понятие стрессоустойчивости имеет англосаксонское происхождение и появилось в дискурсе международных организаций давно, при этом интенсивность обращения к нему поступательно возрастает.

Целью предлагаемого исследования является выявление специфики присутствия стрессоустойчивости в дискурсах Евросоюза и международных организаций, а также взаимосвязей между ними. В исследование были включены организации, имеющие особое значение для европейского интеграционного проекта, а также глобального и регионального управления - Совет Европы, НАТО, ОБСЕ, ОЭСР и организации системы ООН (МВФ, Всемирный банк и т.д.). Поскольку источниковой базой исследования являются, прежде всего, документы международных организаций, в качестве методологической основы был выбран анализ дискурсов.

Проведенный анализ позволил взглянуть на понятие стрессоустойчивости, продвигаемое Брюсселем, более широко - в системе координат глобального и регионального управления, представленного западными многосторонними институтами. В исследовании были определены основные каналы и агенты проникновения понятия в дискурс Евросоюза и других международных организаций. Сделаны выводы относительно схожих черт и противоречий в артикуляции стрессоустойчивости. Отдельное внимание уделено взаимосвязи понятия с неолиберальным подходом к управлению рисками.

Ключевые слова: Европейский союз; ООН; стрессоустойчивость; неолиберализм; безопасность; управление; эксперты

Для цитирования: Трещенков Е.Ю. (2019) Стрессоустойчивость (resilience) в дискурсах Европейского союза и международных организаций // Вестник международных организаций. Т. 14. № 1. C. 55-75. DOI: 10.17323/1996-7845-2019-01-04

\section{Источники}

Луман Н. (1994) Понятие риска // Thesis. Вып. 5. С. 135-160.

Павлова Е.Б., Гудалов Н.Н., Коцур Г.В. (2017) «Стрессоустойчивость»: новое слово в международных отношениях или вариация на неолиберальную тему? // Вестник Московского университета. Сер. 25. Международные отношения и мировая политика. № 2. С. 170-182.

Романова Т.А. (2017) Категория «Стрессоустойчивость» в Европейском Союзе // Современная Европа. № 4. С. 17-28.

Фуко М. (2010) Рождение биополитики. СПб.: Наука.

Anderson B. (2015) What Kind of Resilience? // Politics. Vol. 35. No. 1. P. 60-66.

${ }^{1}$ Статья поступила в редакцию в ноябре 2017 г.

Исследование выполнено за счет гранта Российского научного фонда (проект № 17-18-01110). 
Brand F.S., Jax K. (2007) Focusing the Meaning(s) of Resilience: Resilience as a Descriptive Concept and a Boundary Object // Ecology and Society. Vol. 12. No. 1. Режим доступа: http://www.ecologyandsociety.org/ vol12/iss1/art23/ (дата обращения: 25.10.2017).

Brassett J., Croft S., Vaughan-Williams N. (2013) Introduction: An Agenda for Resilience Research in Politics and International Relations // Politics. Vol. 33. No. 4. P. 222-223.

Council of Europe (c. a.) Complete list of the Council of Europe's treaties. Режим доступа: https://www.coe. int/en/web/conventions/full-list (дата обращения: 25.10.2017).

Council of the European Union (EU) (2013) Council Conclusions on EU Approach to Resilience. Brussels. 28 Мау. Режим доступа: http://www.consilium.europa.eu/uedocs/cms_data/docs/pressdata/EN/foraff/ 137319.pdf (дата обрашения: 25.10.2017).

Council of the European Union (EU) (2017) EU Engagement with Civil Society in External Relations: Council Conclusions. Brussels. 19 June. Режим доступа: https://www.consilium.europa.eu/media/24003/ st10279en17-conclusions-eu-engagement-with-civil-society-in-external-relations.pdf (дата обращения: 25.10.2017)

European Commission (EC) (2012a) SHARE: Supporting Horn of Africa Resilience. Commission Staff Working Document SWD (2012) 102 Final. Brussels. 4 November.

European Commission (EC) (2012b) The EU Approach to Resilience: Learning from Food Security Crises. Communication from the Commission to the European Parliament and the Council COM (2012) 586 Final. Brussels. 3 October.

European Commission (EC) (2013) Cybersecurity Strategy of the European Union: An Open, Safe and Secure Cyberspace. Joint Communication to the European Parliament, the Council, the European Economic and Social Committee and the Committee of the Regions. JOIN (2013) 1 Final. Brussels. 2 July.

European Commission (EC) (2014) EU Resilience Compendium: Saving Lives and Livelihoods. Режим доступа: http://ec.europa.eu/echo/files/policies/resilience/eu_resilience_compendium_en.pdf (дата обращения: 25.10.2017).

European Commission (EC) (2016) Joint Declaration by the President of the European Council, the President of the European Commission and the Secretary General of the North Atlantic Treaty Organization. Brussels. 8 July. Режим доступа: http://europa.eu/rapid/press-release_STATEMENT-16-2459_en.htm (дата обращения: 25.10.2017).

European Parliament (2017) Resilience as a Strategic Priority of the External Action of the EU. Resolution 2017/2594(RSP). Brussels. 1 June. Режим доступа: http://www.europarl.europa.eu/sides/getDoc.do?pubRef=-//EP//TEXT+TA+P8-TA-2017-0242+0+DOC+XML+V0//EN (дата обращения: 25.10.2017).

European Union (EU) (2012) Consolidated Version of the Treaty on European Union. Official Journal of the European Union. 26 October.

European Union (EU) (2016) Shared Vision, Common Action: A Stronger Europe. A Global Strategy for the European Union's Foreign and Security Policy. Режим доступа: https://europa.eu/globalstrategy/en/sharedvision-common-action-stronger-europe (дата обращения: 25.10.2017).

Holling C.S. (1973) Resilience and Stability of Ecological Systems // Annual Review of Ecology and Systematics. Vol. 4. P. 1-23.

International Monetary Fund (IMF) (2005) Remarks by Agustín Carstens, IMF Deputy Managing Director, at the VIII Annual Assembly of Supervisors of Banks of the Americas. 9 September. Режим доступа: http://www. imf.org/en/news/articles/2015/09/28/04/53/sp090905 (дата обращения: 25.10.2017).

International Monetary Fund (IMF) (2015) IMF Survey: Inclusion, Governance, Fiscal Space Can Help Overcome Fragility. Режим доступа: http://www.imf.org/en/news/articles/2015/09/28/04/53/sopol070115a (дата обращения: 25.10.2017).

North Atlantic Treaty Organization (NATO) (2014) Summit Declaration. Wales. 5 September. Режим доступа: http://www.nato.int/cps/en/natohq/official_texts_112964.htm?selectedLocale=en (дата обращения: 25.10.2017).

North Atlantic Treaty Organization (NATO) (2015) Hybrid Warfare: NATO's New Strategic Challenge? Defence and Security Committee General Report DSC 2015. 10 October. Режим доступа: https://www.nato-pa. int/sites/default/files/documents/2015\%20-\%20166\%20DSC\%2015\%20E\%20BIS\%20-\%20HYBRID\%20 WARFARE\%20-\%20CALHA\%20REPORT.docx (дата обращения: 25.10.2017).

North Atlantic Treaty Organization (NATO) (n.d.) Civil Preparedness. Режим доступа: http://www.nato.int/ cps/en/natohq/topics_49158.htm?selectedLocale=en (дата обращения: 25.10.2017). 
Organisation for Economic Co-operation and Development (OECD) (2008) Concepts and Dilemmas of State Building in Fragile Situations: From Fragility to Resilience. OECD/DAC Discussion Рареr. Режим доступа: https://www.oecd.org/dac/conflict-fragility-resilience/docs/41100930.pdf (дата обращения: 25.10.2017).

Organisation for Economic Co-operation and Development (OECD) (2013) What Does "Resilience" Mean for Donors? An OECD Factsheet. Режим доступа: http://www.oecd.org/dac/May\%2010\%202013\%20 FINAL\%20resilience\%20PDF.pdf (дата обращения: 25.10.2017).

Organisation for Economic Co-operation and Development (OECD) (2014a) Guidelines for Resilience Systems Analysis. Strasbourg: OECD Publishing.

Organisation for Economic Co-operation and Development (OECD) (2014b) Overview Paper on Resilient Economies and Societies. Meeting of the OECD Council at Ministerial Level. Paris. 6-7 Мау. Режим доступа: https://www.oecd.org/mcm/C-MIN(2014)7-ENG.pdf (дата обращения: 25.10.2017).

Organization for Security and Co-operation in Europe (OSCE) (2015) Back to Diplomacy: Final Report and Recommendations of the Panel of Eminent Persons on European Security as a Common Project. Режим доступа: http://www.osce.org/networks/205846 (дата обращения: 25.10.2017).

Pawlak P. (2015) Risk and Resilience in Foreign Policy. European Parliamentary Research Service Briefing PE 568.349. Режим доступа: http://www.europarl.europa.eu/RegData/etudes/BRIE/2015/568349/EPRS BRI(2015)568349_EN.pdf (дата обращения: 25.10.2017).

Prasad N., Ranghieri F., Shah F., Trohanis Z., Kessler E., Sinha R. (2009) Climate Resilient Cities: A Primer on Reducing Vulnerabilities to Disasters. Washington, DC: World Bank.

Resilience Alliance (с. а.) Background. Режим доступа: https://www.resalliance.org/background (дата обращения: 25.10.2017).

Shea J. (2016) Resilience: A Core Element of Collective Defence. 2016 NATO Review. Режим доступа: http://www.nato.int/docu/review/2016/Also-in-2016/nato-defence-cyber-resilience/EN/index.htm （дата обращения: 25.10.2017).

Solana H. (1997) Security Through NATO in the 21st Century: Vision to Reality. Opening Remarks. 9 October. Режим доступа: http://www.nato.int/cps/en/natohq/opinions_25565.htm?selectedLocale=en (дата обращения: 25.10.2017).

Thomas J. (2016) Resilience: More Than a Quick Fix. Investing in Health: News and Views in Healthy Development World Bank Blog. Режим доступа: http://blogs.worldbank.org/health/resilience-more-quick-fix (дата обращения: 25.10.2017).

United Nations (UN) General Assembly (2015) Transforming Our World: The 2030 Agenda for Sustainable Development. General Assembly Resolution A/RES/70/1. Режим доступа: http://www.un.org/ga/search/ view_doc.asp?symbol=A/RES/70/1\&Lang=E (дата обращения: 25.10.2017).

United Nations (UN) Secretary-General (2016a) Secretary-General's Joint Press Encounter with the High Commissioner for Refugees. 30 March. Режим доступа: https://www.un.org/sg/en/content/sg/press-encounter/2016-03-30/secretary-generals-joint-press-encounter-high-commissioner (дата обращения: 25.10.2017).

United Nations (UN) Secretary-General (2016b) Secretary-General's Message on Human Rights Day. 10 December. Режим доступа: https://www.un.org/sg/en/content/sg/statement/2016-12-10/secretary-generalsmessage-human-rights-day-scroll-down-french (дата обращения: 25.10.2017).

United Nations (UN) Security Council (2014) The Maintenance of International Peace and Security: Security Sector Reform: Challenges and Opportunities. Security Council Resolution S/RES/2151.

United Nations (UN) Security Council (2017) Threats to International Peace and Security Caused by Terrorist Acts. Security Council Resolution S/RES/2341.

Walker J., Cooper M. (2011) Genealogies of Resilience: From Systems Ecology to the Political Economy of Crisis Adaptation // Security Dialogue. Vol. 4. No. 2. P. 143-160.

World Bank (2015) Big Data for a More Resilient Future. Режим доступа: http://live.worldbank.org/big-datafor-a-more-resilient-future (дата обращения: 25.10.2017).

World Bank (2016a) Speech by World Bank President Jim Yong Kim: The World Bank Group's Mission: To End Extreme Poverty. 3 October. Режим доступа: http://www.worldbank.org/en/news/speech/2016/10/03/ speech-by-world-bank-president-jim-yong-kim-the-world-bank-groups-mission-to-end-extreme-poverty (дата обращения: 25.10.2017).

World Bank (2016b) Socioeconomic Resilience Multi-Hazard Estimates in 117 Countries. World Bank Policy Research Working Paper 7886. 